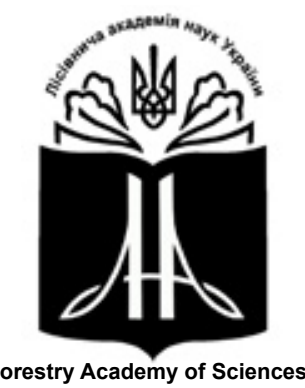

of Ukraine

Наукові праці Лісівничої академії наук України Proceedings of the Forestry Academy of Sciences of Ukraine

http://fasu.nltu.edu.ua

https://doi.org/10.15421/411915

Article received 2018.09.28

Article accepted 2019.03.28
ISSN 1991-606X print

ISSN 2616-5015 online

(a) $\triangle$ Correspondence author

Yuriy Shparyk

yuriy.shparyk@gmail.com

Hrushevskogo str., 31, Ivano-Frankivsk, 76018, Ukraine

УДК $630 * 18: 630 * 187$

\title{
Екологічні наслідки всихання ялинників в основних типах лісу Українських Карпат
}

\author{
Ю.С. Шпарик
}

Стаиіонарні дослідження динаміки всихання ялинових деревостанів Українських Карпат здійснено у 20102014 роках. Аналіз результатів досліджень дав змогу оцінити екологічні наслідки їх всихання за такими типами лісу: вологий кедрово-смерековий субір, волога чиста сусмеречина, волога буково-ялицева сусмеречина, волога буково-смерекова суяличина та волога буково-смерекова яличина. Екологічну ефективності ялинників регіону оцінено в контексті вирішення нагальних екологічних проблем: збереження біорізноманіття, запобігання змінам клімату, покращення комфортності лісів для рекреаційних иілеей.

Встановлено деякі позитивні екологічні наслідки всихання ялинників Українських Карпат. Так, динаміка фiторізноманіття під час всихання ялинників здебільшого (у 91\% випадків) спрямована на збільшення кількості видів рослин. За типами лісу це збільшення становить в межах 57-80\%. Зміни у фіторізноманітті залежать від інтенсивності всихання ялинників. Запас депонованого вуглеию в ялинниках, щзо всихають, переважно (y $55 \%$ випадків) виявляє тенденцію до збільшення. За типами лісу зміни запасів вуглеию змінюються від -11 до $3 \%$ залежно від інтенсивності проведених санітарних рубок. Негативними наслідками всихання ялинників регіону є погіршення їх киснепродукційних функціій на переважній кількості (у 91\% випадків) дослідних об'єктів. За типами лісу зменшення об 'ємів кисню, які продукують ялинники, становить від 4 до 10\%. Величина иього зменшення залежить від участі у складі лісостанів деревних рослин, які продукують кисень, обсяги якого змінюються внаслідок їхнього всихання або зрубування.

Екологічні наслідки всихання ялинників оцінено також за групами віку насаджень $і$ за стадіями всихання.

Ключові слова: ялина європейська; типи деревостанів; групи віку; стадії всихання; фіторізноманіття; депонування вуглецю; продукування кисню.

Вступ. Постійні антропогенні викиди парникових газів та відсутність міжнародного консенсусу щодо пом'якшення наслідків змін клімату свідчать про важливість запобігання цим змінам. Заходи 3 адаптації лісового господарства до змін клімату мають значну тривалість, але також і найвищу ефективність порівняно 3 іншими галузями національного господарства. Відомо, що в процесі фотосинтезу і транспірації ліси поглинають велику кількість сонячної енергії, що істотно впливає на формування мікроклімату. У ширшому розумін- ні ліси протидіють регіональним, континентальним і глобальним змінам клімату (Kirschbaum, 2004, Heerwaarden \& Teuling, 2014, Schlesinger \& Jasechko, 2014, Noormets et al., 2015). Тому підтримання лісового середовища має вирішальне значення для зменшення уразливості лісових екосистем i покращення виконання ними екологічних функцій.

Масове всихання ялинників Карпат за останнє десятиріччя (Mauer \& Palátová, 2010, Debryniuk, 2011, 2014, Janda et al., 2014, FAO, 2016, Shparyk, 2017) має різні за величиною та за напрямом

Шпарик Юрій Степанович - член-кореспондент Лісівничої академії наук України, доктор сільськогосподарських наук, головний науковий співробітник. Український науково-дослідний інститут гірського лісівництва імені П.С. Пастернака, вул. Грушевського, 31 , м. Івано-Франківськ, 76018, Україна. Тел.: 0342-53-02-36, +38-050-188-02-61. E-mail: yuriy.shparyk@gmail.com ORCID: https://orcid. org/0000-0001-8047-6356 
екологічні наслідки: зміна біорізноманіття лісів (Humphrey et al., 2003, Feltonaetal., 2010, Mönkkönen et al., 2011); зменшення обсягів депонованого вуглецю (Dunn et al., 2006, Grünwald \& Bernhofer, 2007, Kurz et al., 2008, Diochon et al., 2009, Šebeň et al., 2015); погіршення киснепродукційної функції лісів (Bergha et al., 1998, Langendörfer et al., 2002, Dunn et al., 2006, Fenton et al., 2009).

За останнє десятиліття стан деревостанів ялини європейської в Українських Карпатах різко погіршився в більшості типів лісу. За роками площа осередків всихання становила від 20 до 50 тис. га, а запаси сухостою - від 3 до 12 млн м³. Масове всихання ялинників відбувається в різних типах лісу і категоріях лісів, незалежно від способів господарювання. Встановлено також наявність успішного природного поновлення під наметом більшості всихаючих ялинників, хоча в ньому і не завжди переважає підріст Picea abaes [L.] Karst., частіше - Fagus sylvatica L. та Abies alba Mill. (Mauer \& Palátová, 2010, Shparyk et al., 2013, 2014, Shparyk, 2017), a також піонерні види дерев, насамперед - Sorbus aucuparia L., що збагачує фіторізноманіття та підвищує стійкість фітоценозу (Šebeň et $\mathrm{al}, 2015)$.

За відсутності природного поновлення на місці загиблих ялинників створюють лісові культури переважно за участю іншої головної породи. Тобто у лісівничому аспекті наслідком всихання ялинників регіону є масова зміна головної породи - ялини на бук або ялицю, але не втрата вкритих лісовою рослинністю ділянок. Однак екологічні наслідки розладнання лісових екосистем ялинників регіону оцінено на теоретичному рівні без достатнього емпіричного обгрунтування (Shparyk et al., 2013, 2014, 2017). У цій роботі зроблено спробу розрахувати величину та напрями цих змін за даними повторних обстежень стаціонарних дослідних об'єктів.

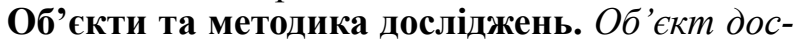
лідження - ялинові ліси, які всихають, в основних типах лісу Українських Карпат. Предмет дослідження - зміни в біорізноманітті, запасах депонованого вуглецю та обсягах продукування кисню в ялинниках регіону, які всихають. Мета дослідження - оцінити величину та напрями змін виконання екологічних функцій ялинників, що всихають в умовах вологого кедрово-смерекового субору, вологої чистої сусмеречини, вологої буково-ялицевої сусмеречини, вологої буково-смерекової суяличини та вологої буково-смерекової яличини. У загальній площі ялинників регіону частка цих типів лісу становить понад $70 \%$. Розрахунок екологічних наслідків всихання ялинників здійснено за результатами дослідження на 21-му постійному дослідному об’єкті (ПДО), які було закладено в 2010 р. і повторно обстежено в 2013-2014 роках (рис. 1).

Об'єкти досліджень підібрані за пропозиціями практиків-лісівників на найхарактерніших для їхніх підприємств лісових ділянках. Дослідні всихаючі ялинники помітно відрізняються за типами лісу, лісівничо-таксаційними показниками, віком, часткою сухостою у загальному запасі деревини. У породному складі всіх ПДО домінує ялина (табл. 1). Лісівничий аналіз деревостанів на ПДО наведено у попередніх публікаціях (Shparyk, 2014, Shparyk, 2017). Усі закладені дослідні об'єкти є типовими для конкретних підприємств.

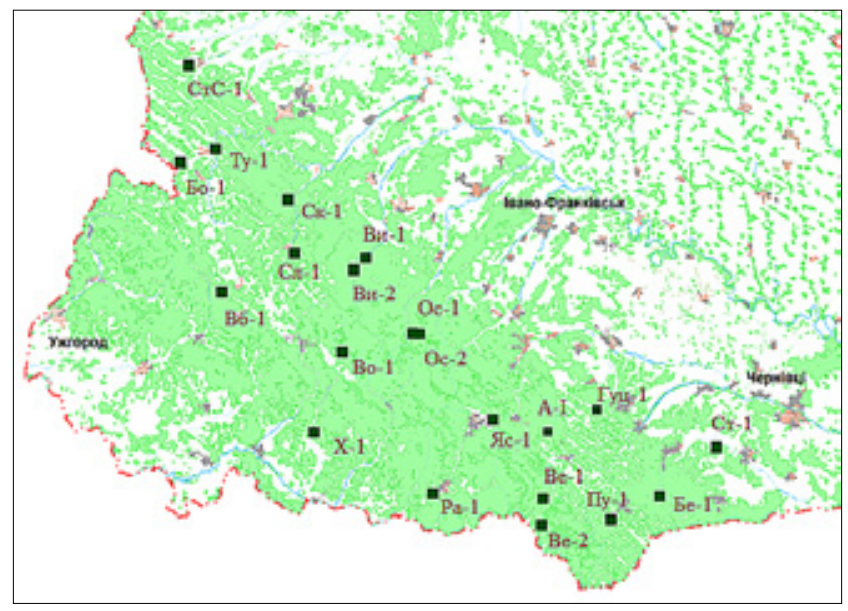

Рис. 1. Розташування постійних дослідних об'єктів (ПДО) у регіоні Українських Карпат

Розрахунок екологічних наслідків всихання ялинників Українських Карпат здійснено на прикладі найважливіших екологічних функцій лісів: збереження фіторізноманіття за кількістю видів рослин; запобігання змінам клімату за запасами депонованого в лісових екосистемах вуглецю; підвищення комфортності лісів для рекреації за об'ємом кисню, який виділяється лісом.

Дослідження проводили методом детального аналізу кожного дерева на ПДО за такими показниками: деревний вид, санітарний стан, діаметр на висоті 1,3 м у двох напрямках 3 точністю вимірювання до 1 мм, клас IUFRO за ярусом, життєвість, положення, функція, товарність і довжина крони, стадії розкладання мертвої деревини (сухостою). Для розрахунку запасів деревини встановлювали висоту модельних дерев, висоту початку крони, діаметр стовбура на висоті 7 м. Мертву лежачу деревину оцінювали за деревним видом, діаметром на середині стовбура (або відрізка стовбура), довжиною стовбура та стадією розкладання. Підріст досліджували на кругових площадках площею $20 \mathrm{~m}^{2}$ кожна 3 розрахунку не менше $10 \%$ площі ПДО за породами та висотними групами (10-30, 31-50, 51-70, 71-90, 91-130, 131 см і вищий). Опис трав'яного вкриття здійснювали на цих же кругових площадках 3 визначенням частки видів за проективним вкриттям. При цьому кількість видів рослин підраховували за ярусами для розуміння їхньої кількісної динаміки, але один і той самий вид у різних ярусах рахували як один вид загалом для коректного оцінювання фіторізноманіття. Навколо кожного ПДО ще відбирали висічки (12-24 шт.) для проведення дендрохронологічного аналізу з таких за показниками дерев, які представлені на ПДО (Shparyk, 2016).

Депонований в ялинниках вуглець оцінювали конверсійно-об'ємним методом, який грунтується 
на конверсійних коефіцієнтах, що представляють собою відношення фітомаси окремих фракцій до запасу деревини на ПДО. Конверсійні коефіцієнти визначено для груп віку і бонітетів окремих порід: ялини і сосни - 0,49, ялиці - 0,48, листяних видів 0,47 , чагарників і підросту всіх порід - 0,48, трав 0,50 . Враховували також вологість живої деревини. У ялини і сосни вона становить 70, у ялиці і берези 80, у бука і дуба - 65, у кленів - 50, у чагарників - 60 i у трав - 90\% (Lakyda, 1998, Vajdanych et al., 2000).

Методика розрахунку об'смів кисню, який виділяє ліс у процесі фотосинтезу, базується на відомому балансі речовин та енергії в процесі фотосинтезу. Маса виділеного лісом кисню і поглиненого вуглекислого газу залежить від початкового і кінцевого станів дерев. У фізичній хімії це закон
Гесса: «Енергетичний ефект хімічних перетворень залежить тільки від початкового і кінцевого станів системи, але не залежить від шляху, по якому реакції протікають». Це означає, що маса кисню, яку виділяє дерево, репрезентує його щорічний приріст фітомаси, а загальна маса виділеного кисню за весь період росту дерев визначається запасом органічної маси лісової екосистеми. У роботі використано такі коефіцієнти для переведення приросту фітомаси в об'єм кисню, виділеного різними породами (з розмірністю - кілограм виділеного кисню на кілограм приросту), які становлять для сосни - 1,398, ялини 1,413 , берези - 1,393, бука $-1,428$ і дуба $-1,426$. Ці коефіцієнти були інтерпольовані для інших порід на всіх ПДО залежно від щільності їхньої деревини (Belov, 1983, Lakyda \& Blyschyk, 2014).

\section{Основні лісівничо-таксаційні показники деревостанів на ПДО}

Таблицяя 1

\begin{tabular}{|c|c|c|c|c|c|c|c|c|}
\hline \multirow[b]{2}{*}{ пдО } & \multirow[b]{2}{*}{$\begin{array}{l}\text { Індекс типу } \\
\text { лісу }\end{array}$} & \multirow[b]{2}{*}{$\begin{array}{c}\text { Склад } \\
\text { деревостану }\end{array}$} & \multirow[b]{2}{*}{$\begin{array}{c}\text { К-ть } \\
\text { ярусів, } \\
\text { шт. }\end{array}$} & \multirow[b]{2}{*}{$\begin{array}{l}\text { Вік, } \\
\text { років }\end{array}$} & \multirow[b]{2}{*}{ 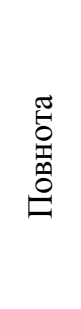 } & \multirow[b]{2}{*}{ 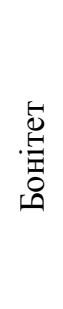 } & \multicolumn{2}{|c|}{$\begin{array}{c}\text { Запас стовбурової } \\
\text { деревини }\end{array}$} \\
\hline & & & & & & & 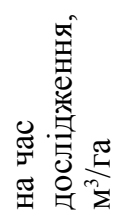 & 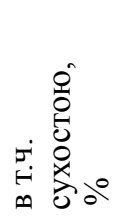 \\
\hline Oc-2 & $\mathrm{B}_{3}-\mathrm{KCM}$ & 9Ял1Ске + Яц & 3 & 121 & 0,50 & II & 528,3 & 30,1 \\
\hline$X-1$ & $\mathrm{C}_{3}$-Бк & 9Ял1Сз & 1 & 53 & 0,40 & $\mathrm{I}^{\mathrm{B}}$ & 272,8 & 0,0 \\
\hline $\mathrm{Be}-2$ & $\mathrm{C}_{3}-\mathrm{CM}_{\mathrm{M}}$ & 10Ял & 3 & 131 & 0,88 & II & 668,7 & 8,5 \\
\hline Гуц-1 & $\mathrm{C}_{3}-\mathrm{CM}_{\mathrm{M}}$ & 10Ял & 2 & 153 & 0,92 & II & 685,5 & 7,6 \\
\hline Pa-1 & $\mathrm{C}_{3}-\mathrm{CM}_{\mathrm{M}}$ & 10Ял + Бк & 3 & 202 & 0,47 & II & 454,0 & 23,8 \\
\hline A-I & $\mathrm{C}_{3}-\mathrm{CM}_{\mathrm{M}}$ & 10Ял + Гор & 3 & 220 & 0,94 & II & 700,3 & 1,9 \\
\hline Oc-1 & $\mathrm{C}_{3}-б \kappa \mathrm{M}$ & 10Ял + Ске & 3 & 131 & 0,65 & III & 380,2 & 4,1 \\
\hline Ви-2 & $\mathrm{C}_{3}-б \kappa-я ц С м$ & 10Ял + Яв & 2 & 78 & 0,79 & I & 760,3 & 6,9 \\
\hline Яc-1 & $\mathrm{C}_{3}$-бк-яцСм & 10Ял & 2 & 101 & 0,98 & I & 861,5 & 10,7 \\
\hline Ви-1 & $\mathrm{C}_{3}$-бк-яцСм & 5Ял4Яц1Яв + Б & 3 & 115 & 1,10 & II & 791,6 & 18,6 \\
\hline $\mathrm{Be}-1$ & $\mathrm{C}_{3}$-бк-яцСм & 6Ял2Яц2Бк + Яв & 3 & 165 & 0,90 & II & 778,6 & 37,1 \\
\hline СтC-1 & $\mathrm{C}_{3}-б \kappa Я ц$ & 6Ял2Яц1Бк1Сз + Яв, Яс, Гор & 3 & 73 & 1,02 & II & 533,0 & 6,7 \\
\hline Ty-1 & $\mathrm{C}_{3}-$-бк-смЯц & 10Ял & 2 & 43 & 0,44 & I & 166,1 & 2,0 \\
\hline Бе- 1 & $\mathrm{C}_{3}$-бк-смЯц & 10Ял & 3 & 51 & 0,74 & $\mathrm{I}^{\mathrm{a}}$ & 469,5 & 1,4 \\
\hline Пу-1 & $\mathrm{C}_{3}-$-бк-смЯц & 10Ял + Бк, Яц & 3 & 83 & 0,69 & I & 597,8 & 2,1 \\
\hline Bo-1 & $\mathrm{D}_{3}$-яцБк & 9Ял1Яц + Яв,Вз, Бк & 2 & 67 & 0,85 & $\mathrm{I}^{\mathrm{B}}$ & 763,0 & 11,1 \\
\hline Бо-2 & $\mathrm{D}_{3}$-бк-яцСм & 5Ял5Яц + Ос & 1 & 28 & 1,18 & II & 187,7 & 2,2 \\
\hline Ст-1 & $\mathrm{D}_{3}$-бк-смЯц & 10Ял + Бк, Яц, Б, Г, Дз, Лп, Яв & 3 & 46 & 0,84 & I & 394,9 & 16,6 \\
\hline Вб-1 & $\mathrm{D}_{3}$-бк-смЯц & 9Ял1Яц + Яв,Бк & 3 & 55 & 0,69 & $\mathrm{I}^{\mathrm{a}}$ & 510,0 & 14,6 \\
\hline Сл-1 & $\mathrm{D}_{3}-$-б-смЯц & 10Ял +Бк, Яв & 3 & 61 & 0,90 & I & 530,4 & 4,7 \\
\hline Ск-1 & Dз-бк-смЯц & 9Ял1Бк & 3 & 114 & 0,95 & I & 726,0 & 11,6 \\
\hline
\end{tabular}

Примітка. У номері ПДО зашифровано назву підприємства

Результати дослідження. Попередні дослідження фіторізноманіття лісів Українських Карпат не дали змоги встановити достовірної різниці в динаміці кількості видів рослин у різних категоріях лісів, за умови належного ведення лісового госпо- дарства. Так, на двох із чотирьох дослідних ділянок у природоохоронних лісах за період 1999-2005 pp. фіторізноманіття збільшилось, а на двох - зменшилося. Суттєві зміни (на рівні $18 \%$ ) відбулися лише на одному об'єкті - в бік зменшення видового різ- 
номаніття рослин. За типами лісу найстабільнішою була ситуація у вологій буково-ялицевій сусмеречині, незважаючи на відмінності у типах деревостанів та методах господарювання. Встановлено, що визначальним чинником фіторізноманіття $€$ морфологічні показники деревостанів (повнота, зімкненість крон, ярусність), а не типи лісу чи категорії лісів (Shparyk, 2014, 2016).

Аналіз видового різноманіття всихаючих ялинників свідчить про значну його мінливість у різних типах лісу. Так, середня кількість видів рослин змінюється від 8 (волога буково-смерекова суяличина) до 18 (волога буково-смерекова яличина). Варіювання цього показника змінюється від 12 (волога буково-смерекова суяличина) до 37 \% (волога чиста сусмеречина) (рис. 2).

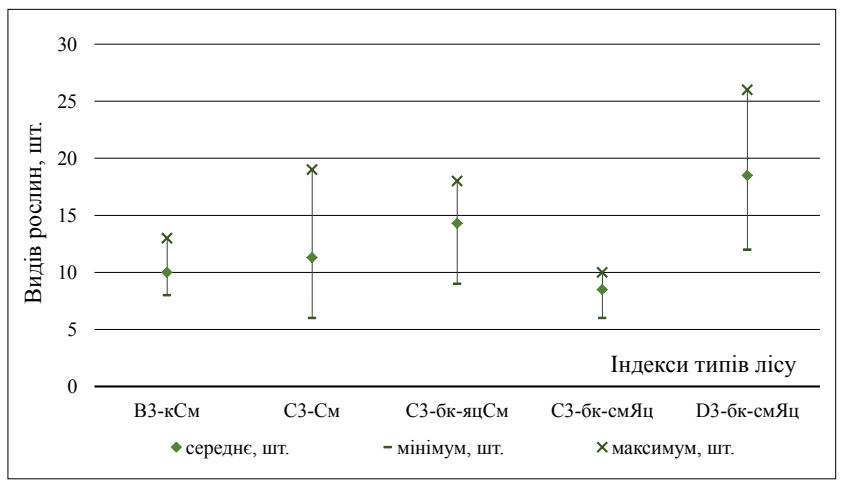

Рис. 2. Фіторізноманіття ялинників Українських Карпат

Дослідження динаміки кількості видів у ялинниках упродовж 2010-2014 pр. показало, що в межах одного типу лісу варіабельність становила 8-150\%, а в межах різних типів лісу $-57-80 \%$.

Результати статистичного аналізу свідчать про відсутність чітких залежностей між змінами у фіторізноманітті і таксаційними показниками ялинників. Найбільші 3 них досягають помірного зворотного кореляційного зв'язку між динамікою кількості видів у деревостанах та їхнім віком $(\mathrm{r}=-0,302)$ та слабкого - 3 часткою ялини в їхньому породному складі $(\mathrm{r}=-0,278)$. На $91 \%$ дослідних ділянок всихаючих ялинових деревостанів встановлено збільшення кількості видів (табл. 2). Простежується загальна тенденція до зменшення зміни фіторізноманіття в середньовікових $(23,5 \%)$ всихаючих ялинниках і збільшення у пристиглих $(85,0 \%)$ та зменшення у стиглих і перестійних - до $42-47 \%$. Це пояснюють максимальним зменшенням повноти деревостанів саме у пристиглих ялинниках. Аналогічні закономірності у формуванні фіторізноманіття всихаючих ялинників встановлено в межах типів лісу, за винятком вологої буково-смерекової яличини, де зменшення кількості видів зафіксовано вже у пристиглих деревостанах.

Також встановлено чіткі закономірності зміни фіторізноманіття у всихаючих ялинниках, які пов'язані зі стадіями всихання. Найменше його зниження (на $33 \%$ ) встановлено на стадії стабілізації процесів всихання, а найбільше (на $62 \%$ ) - на по- чатковій стадії (див. табл. 2). Таку закономірність можна пояснити максимальним зменшенням повноти деревостанів ялини саме на стадії початкового всихання. Аналогічні закономірності зміни у фіторізноманітті на різних стадіях всихання ялинників встановлено і в межах типів лісу. Проте в умовах вологої буково-ялицевої сусмеречини існує практично зворотна тенденція, де зміни у фіторізноманітті $€$ мінімальними на стадії прогресуючого всихання, а максимальними - на стадії стабілізації всихання. Такий стан $\epsilon$ наслідком завершення переформування похідних ялинників із низьким фіторізноманіттям на корінні мішані ялинники з високим фіторізноманіттям саме на стадії стабілізації.

Вплив всихання ялини проявляється також на формуванні запасу депонованого вуглецю в дослідних лісостанах. За середнього запасу вуглецю 85,5 т/га, коливання цього показника у дослідних всихаючих ялинниках становить від 62,3 (волога буково-смерекова суяличина) до 123,7 т/га (волога буково-ялицева сусмеречина) за мінливості показника $36,6 \%$ (рис. 3 ). Визначальним показником для обсягів депонування вуглецю лісостанами $є$ запас деревини, де його частка в середньому сягає $83 \%$, зокрема на перший ярус припадає 71 , на другий 11 і на третій - $1 \%$. Частка сухостою в запасі депонованого вуглецю в середньому становить 10,6, мертвої лежачої деревини $-5,5$, трави $-0,5$, підросту $-0,3$ і підліску $-0,1 \%$.

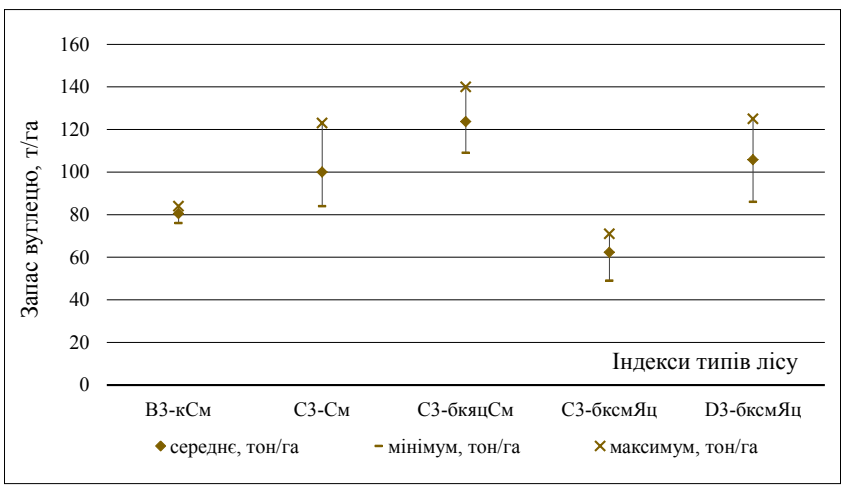

Рис. 3. Запас депонованого вуглецю в ялинниках Українських Карпат

Запас вуглецю в дослідних ялинниках значною мірою корелює 3 віком деревостанів і меншою мірою визначається типом лісорослинних умов та головною породою. Коефіцієнт кореляції між віком всихаючих ялинників і запасом вуглецю виявився прямим і помірним $(\mathrm{r}=0,38)$.

Динаміка запасу депонованого вуглецю у всихаючих ялинниках має тенденцію до збільшення 3 віком деревостанів, що зумовлено збільшенням обсягів мертвої деревини та кількості підросту. У різних груп ці зміни змінюються від $-5,4$ до 3,0\%, a їх тенденція полягає у збільшенні від мінімальних значень запасу вуглецю у середньовікових, до максимальних - у пристигаючих ялинниках та подальшому поступовому його зменшенні у стиглих і перестиглих лісостанах (табл. 3). 
Таблиия 2

Зміни фіторізноманіття всихаючих ялинників різних типів лісу, груп віку і стадій всихання, \%

\begin{tabular}{|c|c|c|c|c|c|c|}
\hline \multirow{2}{*}{ Показник } & \multicolumn{5}{|c|}{ Індекс типу лісу } & \multirow{2}{*}{ Середнє } \\
\hline & $\mathrm{C}_{3}-б \kappa-с м Я ц$ & $\mathrm{D}_{3}$-бк-смЯц & $\mathrm{B}_{3}-\kappa \mathrm{CM}$ & $\mathrm{C}_{3}$-бк-яцСм & $\mathrm{C}_{3}-\mathrm{CM}$ & \\
\hline \multicolumn{7}{|c|}{ Група віку } \\
\hline Середньовікові & - & 23,5 & - & - & - & 23,5 \\
\hline Пристиглі & 150,0 & 20,0 & - & - & - & 85,0 \\
\hline Стиглі & 54,5 & - & - & 58,3 & 26,7 & 46,5 \\
\hline Перестиглі & - & - & 80,0 & 56,7 & 8,3 & 42,0 \\
\hline \multicolumn{7}{|c|}{ Стадія всихання } \\
\hline Початкова & 102,3 & 20,0 & - & 58,3 & 25,0 & 61,6 \\
\hline Прогресуюча & - & 23,5 & 80,0 & 33,3 & - & 45,6 \\
\hline Стабілізації & - & - & - & 80,0 & 9,2 & 32,8 \\
\hline Середнє: & 102,3 & 21,8 & 80,0 & 57,2 & 14,4 & 49,4 \\
\hline
\end{tabular}

Зміна запасу депонованого вуглецю у всихаючих ялинників, \%

Таблицяя 3

\begin{tabular}{|c|c|c|c|c|c|c|}
\hline \multirow{2}{*}{ Показник } & \multicolumn{5}{|c|}{ Індекс типу лісу } & \multirow{2}{*}{ Середнє } \\
\hline & $\mathrm{C}_{3}$-бк-смЯц & $\mathrm{D}_{3}$-бк-смЯц & $\mathrm{B}_{3}-\mathrm{KCM}$ & $\mathrm{C}_{3}$-бк-яцСм & $\mathrm{C}_{3}-\mathrm{CM}_{\mathrm{M}}$ & \\
\hline \multicolumn{7}{|c|}{ Група віку } \\
\hline Середньовікові & - & 0,50 & - & - & - & 0,50 \\
\hline Пристиглі & 4,28 & 1,75 & - & - & - & 3,02 \\
\hline Стиглі & 1,23 & - & - & $-5,18$ & $-0,66$ & $-1,54$ \\
\hline Перестиглі & - & - & 1,27 & $-13,81$ & $-0,23$ & $-5,36$ \\
\hline \multicolumn{7}{|c|}{ Стадія всихання } \\
\hline Початкова & 2,75 & 1,75 & - & $-5,18$ & $-1,01$ & 0,21 \\
\hline Прогресуюча & - & 0,50 & 1,27 & $-20,36$ & - & $-6,19$ \\
\hline Стабілізації & - & - & - & $-7,25$ & $-0,06$ & $-2,45$ \\
\hline Серед & 2,75 & 1,13 & 1,27 & $-10,93$ & $-\mathbf{0 , 3 8}$ & $-2,26$ \\
\hline
\end{tabular}

У середньовікових і пристиглих ялинниках втрати запасу деревини від всихання та гниття перекриваються поточним іiі приростом і в пристиглих ялинниках цей тренд досягає максимуму через обмеження рубок догляду. У стиглих і перестиглих ялинниках приріст деревини зменшується, а інтенсивність всихання дерев зростає, а тому збільшення запасів вуглецю не відбувається. Аналогічні тенденції зміни відносних обсягів депонованого вуглецю у всихаючих ялинниках проявляються в різних типах лісу, за винятком вологої чистої сусмеречини та вологого кедрово-смерекового субору.

Зміни запасу депонованого вуглецю в ялинниках різних стадій всихання становлять від 0,2 до $-6,2 \%$. На початковій стадії всихання встановлено збільшення запасу депонованого вуглецю, а на стадіях прогресуючого всихання і стабілізації всихання зареєстровано його втрати. Це зумовлено найбільшими втратами запасу ялини саме на стадії прогресуючого всихання, коли ії деревина вилучається 3 деревостанів у процесі санітарних рубок. Значні втрати деревини внаслідок всихання ялини тривають також і на стадії стабілізації всихання та після iї завершення.
Аналіз киснепродуктивності лісових екосистем на ПДО свідчить про значну мінливість сумарних обсягів продукування кисню ялинниками за весь період росту (рис. 4).

За середньої киснепродуктивності на рівні 340,2 т/га, іiі значення у всихаючих ялинниках становлять від 239 (вологий кедрово-смерековий субір) до 425 т/га (волога буково-ялицева сусмеречина) (див. рис. 4). Мінливість кисневої продуктивності становила $35,6 \%$. Визначальним для обсягів продукування кисню ялинниками за весь період росту є запас деревини, де його частка в середньому сягає $99 \%$, зокрема на перший ярус припадає 84 , на другий -14 і на третій - лише $1 \%$. При цьому, внесок підросту у киснепродуктивність у середньому становить 0,6 , трав - 0,4 і підліску $-0,3 \%$. Обсяг продукування кисню в ялинниках слабо залежить від типу лісу.

Встановлено слабкий вплив на кисневу продуктивність основних лісівничо-таксаційних показників деревостанів (віку, типу лісу, типотвірної породи). Для ялинових типів лісу обсяги продукування кисню становили від 120,6 до 491,5, а для ялицевих - від 110,6 до 531,7 т/га. 


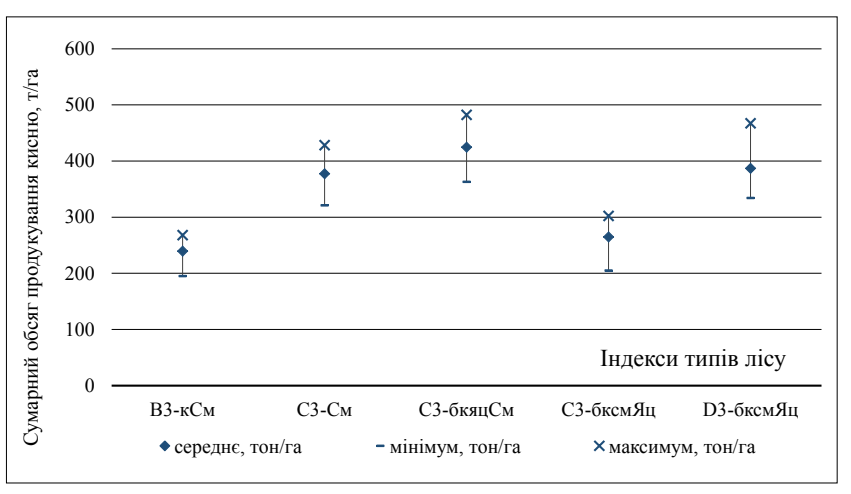

Рис. 4. Сумарний обсяг продукування кисню в ялинниках Українських Карпат

Аналіз змін продукування кисню всихаючими ялинниками в період між інвентаризаціями підтвердив значні їхні коливання. Так, у $91 \%$ ялинових деревостанів встановлено зниження кисневої продуктивності до $24,6 \%$ і тільки у $9 \%$ - зростання до 7,5\% (табл. 4). Такі зміни зумовлені зменшенням унаслідок всихання кількості живих дерев ялини, які в процесі життєдіяльності виділяють кисень. Зі збільшенням віку ялинових деревостанів втрати обсягів продукування кисню зростають. З'ясовано, що в середньовікових і пристиглих деревостанах зниження виділення обсягів кисню становить 6,2$7,0 \%$, а в стиглих і перестиглих - 8,1-9,2\% (табл. 4). Це зумовлено тим, що в середньовікових і пристиглих ялинниках втрати запасу деревини від всихання повністю перекриваються поточним приростом деревини. Зі збільшенням віку прирости деревини зменшуються, а інтенсивність всихання ялини зростає, а тому збільшення киснепродуктивності у стиглих ялинниках не відбувається.

Зменшення обсягів продукування кисню всихаючими ялинниками на різних стадіях всихання становить від 0,08 до $11,92 \%$. На початковій стадії всихання встановлено зменшення об'єму продукування кисню на рівні $10 \%$, а на стадії прогресуючого всихання - на $12 \%$. Водночас на стадії стабілізації всихання ці втрати стають мінімальними (див. табл. 4). Це пов'язано з максимальними втратами органічної маси деревостанів саме на стадіях початкового та прогресуючого всихання. На стадії стабілізації всихання деревостани вже розладнані i до продукування кисню долучається підріст тих деревних видів, які виросли на місцях сухостою ялини. У межах типів лісу найменші втрати кисню $(4,19 \%)$ встановлено в умовах вологого кедровосмерекового субору. В умовах вологої буковоялицевої сусмеречини, вологої чистої сусмеречини і вологої буково-смерекової яличини вони зросли до 8,04-9,64\%. У переважній кількості типів лісу найбільші втрати кисню визначені на початковій стадії всихання деревостанів і тільки в умовах вологої буково-ялицевої сусмеречини - на прогресуючій стадії. На нашу думку, така ситуація $\epsilon$ наслідком більш інтенсивної втрати органічної маси у процесі всихання ялини, тоді як інші лісотвірні породи (бук і ялиця) мають значно вищу біотичну стійкість у цьому типі лісу.

Зміни об'смів продукування кисню всихаючими ялинниками, \%

Таблиця 4

\begin{tabular}{|c|c|c|c|c|c|c|}
\hline \multirow{2}{*}{ Показник } & \multicolumn{5}{|c|}{ Індекс типу лісу, \% } & \multirow{2}{*}{ Середнє } \\
\hline & $\mathrm{C}_{3}$-бк-смЯц & $\mathrm{D}_{3}$-бк-смЯц & $\mathrm{B}_{3}-\mathrm{KCM}$ & $\mathrm{C}_{3}$-бк-яцСм & $\mathrm{C}_{3}-\mathrm{CM}_{\mathrm{M}}$ & \\
\hline \multicolumn{7}{|c|}{ Група віку деревостанів } \\
\hline Середньовіковий & - & $-6,98$ & - & - & - & $-6,98$ \\
\hline Пристиглий & $-2,42$ & $-9,99$ & - & - & - & $-6,21$ \\
\hline Стиглий & $-10,90$ & - & - & $-11,85$ & $-4,70$ & $-9,15$ \\
\hline Перестиглий & - & - & $-4,19$ & $-8,53$ & $-9,71$ & $-8,13$ \\
\hline \multicolumn{7}{|c|}{ Стадія всихання } \\
\hline Початкова & $-6,66$ & $-9,99$ & & $-11,85$ & $-16,34$ & $-10,30$ \\
\hline Прогресуюча & - & $-6,98$ & $-4,19$ & $-24,59$ & - & $-11,92$ \\
\hline Стабілізації & - & - & - & 7,53 & $-3,89$ & $-0,08$ \\
\hline Середне & $-6,66$ & $-8,49$ & $-4,19$ & $-9,64$ & $-8,04$ & $-7,96$ \\
\hline
\end{tabular}

Висновки. Динаміка фіторізноманіття у переважної кількості $(91 \%)$ всихаючих ялинників спрямована на збільшення кількості видів рослин у лісостанах і $є$ позитивною тенденцією. У межах типів лісу збільшення фіторізноманіття ялинників становить переважно від 57 до $80 \%$. За групами віку найменші зміни фіторізноманіття виявлено у середньовікових деревостанах, а найбільші $(80 \%)$ - у пристиглих. Встановлено достовір- ну тенденцію до зменшення інтенсивності зміни кількості видів від стадії початкового всихання до стадії стабілізації всихання. Домінуючим чинником для детермінації динаміки фіторізноманіття $є$ повнота деревостанів, яку визначає інтенсивність процесів всихання.

Встановлено зростання запасів депонованого вуглецю в $55 \%$ всихаючих ялинників, яке детермінується кількістю та інтенсивністю санітарних 
рубок. Ця тенденція зумовлена зростанням обсягів ще не розкладеної мертвої деревини та кількістю підросту під наметом деревостанів. Найбільші зміни у запасі вуглецю встановлено в умовах вологої буково-смерекової суяличини i вологої буковоялицевої сусмеречини. За групами віку зміни запасу вуглецю мають тренд до збільшення від мінімуму у середньовікових до максимуму - у пристиглих ялинниках. За стадіями всихання динаміка депонування вуглецю характеризується максимумом на початковій стадії і мінімумом на стадії прогресуючого всихання та середніми значеннями - на стадії стабілізації всихання.

У $91 \%$ ялинників встановлено зниження інтенсивності виділення кисню внаслідок зменшення кількості дерев, які продукують кисень. Встановлено збільшення втрат обсягів продукування кисню від середньовікових та пристиглих до стиглих ялинників. Зменшення обсягів продукування кисню ялинниками за стадіями всихання становлять від 0,08 до - $11,92 \%$. Найбільшими вони виявились на початковій стадії всихання (10\%) і стадії прогресуючого всихання (12\%).

Екологічні наслідки всихання ялинників Українських Карпат можуть бути як позитивними (збільшення фіторізноманіття, поступове формування стійких мішаних деревостанів на місці похідних, за відсутності санітарних рубок - збільшення запасів депонованого вуглецю), так і негативними (зменшення запасів депонованого вуглецю у разі здійснення санітарних рубок, зменшення обсягів продукування кисню).

\section{Бібліографічні посилання}

Belov, S. V. (1983). Forestry. Moscow: Forest industry (in Russian).

Bergha, J., McMurtrieb, R.E., \& Linder, S. (1998) Climatic factors controlling the productivity of Norway spruce: A model-based analysis. Forest Ecology and Management, 110 (1-3), 127-139. https://doi.org/10.1016/S0378-1127(98)00280-1

Debryniuk, Iu.M. (2011). Dieback of the spruce forests: causes and consequences. Scientific bulletin of the Ukrainian State Forestry University, 21.16, 3238 (in Ukrainian).

Debryniuk, Iu. M. (2014). Formative variety and Life condition of Picea abies [L.] Karst. in the Western Forest-steppe of Ukraine. Journal of Agrobiology and Ecology, 4 (1), 97-102 (in Ukrainian).

Diochon, A., Kellman, L., \& Beltrami H. (2009). Looking deeper: An investigation of soil carbon losses following harvesting from a managed northeastern red spruce (Picearubens Sarg.) forest chronosequence. Forest Ecology and Management, 257 (2), 413-420. https://doi.org/10.1016/j.foreco.2008.09.015

Dunn, A.L., Barford, C.C., Wofsy, S.C., Goulden, M.L., \& Daube, B.C. (2006). A long-term record of carbon exchange in a boreal black spruce forest: means, responses to interannual variability, and decadal trends. Global Change Biology, 13 (3), 577-590. Retrieved from http://onlinelibrary.wiley. com/doi/10.1111/j.1365-2486.2006.01221.x/full

FAO (2016). Global forest resources assessment 2015. How are the world's forests changing? Second edition. Rome, FAO. Retrived from http://www.fao. org/3/a-i4793e.pdf.

Feltona, A., Lindbladha, M., Bruneta, J., \& Fritz, Ö. (2010). Replacing coniferous monocultures with mixed-species production stands: An assessment of the potential benefits for forest biodiversity in northern Europe. Forest Ecology and Management, 260 (6), 939-947. https://doi.org/10.1016/j.foreco. 2010.06.011

Fenton, N.J., Simard, M., \& Bergeron, Y. (2009). Emulating natural disturbances: the role of silviculture in creating even-aged and complex structures in the black spruce boreal forest of eastern North America. Journal of Forest Research, 14 (5), 258-267. https:// doi.org/10.1007/s10310-009-0134-8

Grünwald, T., \& Bernhofer, C. (2007). A decade of carbon, water and energy flux measurements of an old spruce forest at the Anchor Station Tharandt. Retrieved from http://onlinelibrary.wiley.com/ doi/10.1111/j.1600-0889.2007.00259.x/full

Heerwaarden, C.C., \& Teuling, A.J. (2014). Disentangling the response of forest and grassland energy exchange to heatwaves under idealized landatmosphere coupling. Biogeosciences, 11, 61596171. https://doi.org/10.5194/bg-11-6159-2014

Humphrey, J., Ferris, R., Jukes, M., \& Peace A. (2003). Biodiversity in Planted Forests. Retrieved from https://www.forestry.gov. uk/pdf/ frbiodiversityplantedforests0001.pdf

Janda, P., Svoboda, M., Bače, R., Čada, V., Lynn, J., $\&$ Peck, E. (2014). Three hundred years of spatiotemporal development in a primary mountain Norway spruce stand in the Bohemian Forest, central Europe. Forest Ecology and Management, 330, 304311. https://doi.org/10.1016/j.foreco.2014.06.041

Kirschbaum, M.U.F. (2004). Direct and indirect climate change effects on photosynthesis and transpiration. Plant Biology, 6, 242-253. https://doi. org/10. 1055/s-2004-820883

Kurz, W.A., Dymond, C. C., Stinson, G., Rampley, G. J., Neilson, E. T., Carroll, A. L., ... Safranyik, L. (2008). Mountain pine beetle and forest carbon feedback to climate change. Nature, 452, 987-990. https://doi. org/10.1038/nature06777

Lakyda, P. I. (1998). Methodological aspects of the annual carbon stock estimation in the forest stands. Scientific bulletin of the NAU:Forestry, 8, 221-227 (in Ukrainian).

Lakyda, P.I., \& Blyschyk, V.I. (2014). Forecast of carbon stock and oxygen production of alder forest in Ukrainian Polissya. Bioresources and nature management, 6 (1-2), 91-98 (in Ukrainian).

Langendörfer, U., Cuntz, M., Ciais, P., Peylin, P., Bariac, T., Milyukova, I., ... Naegler, T. (2002). Modelling of biospheric $\mathrm{CO}_{2}$ gross fluxes via 
oxygen isotopes in a spruce forest canopy: a $222 \mathrm{Rn}$ calibrated box model approach. Retrieved from http://onlinelibrary.wiley.com/doi/10.1034/j.16000889.2002.01345.x/full

Mauer, O., \& Palátová, E. (2010). Decline of Norway spruce in the Krkonoše Mts. Journal of Forest Science, 56, 361-372. https://doi.org/10.17221/95/2009-JFS

Mönkkönen, M., Reunanen, P., Kotiaho, J. S., Juutinen, A., Tikkanen, O.-P., \& Kouki, J. (2011). Cost-effective strategies to conserve boreal forest biodiversity and long-term landscape-level maintenance of habitats. European Journal of Forest Research. 130 (5), 717726. https://doi.org/10.1007/s10342-010-0461-5

Noormets, A., Epron, D., Domec, J. C., McNulty, S. G., Fox, T., Sun, G., \& King, J.S. (2015). Effects of forest management on productivity and carbon sequestration: A review and hypothesis. Forest Ecology and Management, 355, 124-140. https://doi. org/10.1016/j.foreco.2015.05.019

Schlesinger, W.H., \& Jasechko, S. (2014). Transpiration in the global water cycle. Agricultural and Forest Meteorology, 189-190, 115-117. https:// doi.org/10.1016/j.agrformet.2014.01.011

Šebeň, V., Konôpka, B., Bošel'a1, M., \& Pajtík, J. (2015). Contrasting development of declining and living larch-spruce stands after a disturbance event: a case study from the High Tatra Mts. Lesnicky Casopis - Forestry Journal, 61, 157-166. https://doi. org/10.1515/forj-2015-0024

Shparyk, Y.S. (2014). Form diversity and health conditions of Norway spruce (Picea abies (L.) Karst.) in the main forest types of the Ukrainian Carpathians. Forestry \& Agroforestmelioration, 125, 87-96 (in Ukrainian).

Shparyk, Y.S. (2016). Sustainable forest management (on the example of the Ukrainian Carpathians). Ivano-Fankivsk: Printing area (in Ukrainian).

Shparyk, Y.S. (2017). Economic results of spruce forests' decline in the Ukrainian Carpathians. Scientific works of the Ukrainian Forestry Academy of Sciences, 15, 129-139. https://doi. org/10.15421/411717(in Ukrainian).

Shparyk, Y.S., Parpan, T.V., Slobodyan, P.Y., Savchyn, T. I., \& Bunij, V.Y. (2013). Spruce forest decline on the north-eastern megaslope of the Ukrainian Carpathians. Scientific bulletin of the Ukrainian National Forestry University, 23.5, 141147 (in Ukrainian).

UkrRIMF (2014). Studying of Spruce forests decline reasons in the Carpathian region for the forestry instruction preparation on the management plane for these forests and on the forestry actions for their transformation on native stands. Final report. IvanoFrankivs'k, UkrRIMF (in Ukrainian).

Vajdanych, T.V., Dejneka, A.M., \& Myklush, S.I. (2000). Method for mass determining of photosynthetic bound atmospheric carbon dioxide and deposited carbon in the forest stands. Patent of Ukraine, 45794, 5 (in Ukrainian).

\section{Экологические последствия усыхания ельников в основных типах леса Украинских Карпат}

\author{
Ю.С. Шпарык ${ }^{1}$
}

Стационарные исследования динамики усыхания еловых древостоев Украинских Карпат проведены на 21 пробной площади на протяжении 2010-2014 годов. Анализ результатов исследований позволил оценить экологические последствия усыхания ельников в следующих типах леса: влажная кедрово-еловая суборь, влажная чистая сурамень, влажная буково-пихтовая сурамень, влажный буково-еловый супихтач и влажный буково-еловый пихтач. Оценка экологической эффективности ельников региона проведена в контексте решения насущных экологических проблем: сохранение биоразнообразия, предупреждение изменений климата, улучшение комфортности лесов для рекреации.

Динамика фиторазнообразия усыхающих ельников в подавляющем большинстве (на 91\% объектов) направлена на увеличение количества видов растений - в среднем на 49\%. По типам леса это увеличение составляет от 20 до $80 \%$. По группам возраста наименьшее увеличение имеет место в средневозрастных древостоях (23\%), максимальное $(86 \%)$ - в приспевающих. В спелых и перестойных усыхающих ельниках увеличение фиторазнообразия составило 42-46\%. По стадиям усыхания установлена достоверная тенденция к уменьшению интенсивности возрастания количества видов от стадии начального усыхания к стадии стабилизации усыхания. Ключевым фактором для детерминации динамики фиторазнообразия является интенсивность усыхания ельников.

Динамика запаса депонированного углерода в усыхающих ельниках в большинстве (на 55\% объектов) направлена на его увеличение, но среднее значение составляет $-2,3 \%$. Этот факт обусловлен ростом объемов мертвой лежащей древесины и количеством подроста на фоне уменьшения запаса древостоя. Максимальные изменения запаса углерода установлены в условиях влажного буково-елового супихтача $(+3 \%)$ и влажной буково-пихтовой сурамени (-11\%). По группам возраста запас углерода увеличивается в средневозрастных и приспевающих ельниках, но уменьшается - в спелых и перестойных древостоях. По стадиям усыхания изменения запаса углерода характеризуются максимумом $(+0,2 \%)$ на начальной стадии, минимумом $(-6,2 \%)$ - на стадии прогрессирующего и средними значениями $(-2,5 \%)$ - на стадии стабилизации усыхания. Детер-

\footnotetext{
Шпарык Юрий Степанович-член-корреспондент Лесной академии наук Украины, доктор сельскохозяйственных наук, главный научный сотрудник. Украинский научно-исследовательский институт горного лесоводства имени П.С. Пастернака, ул. Грушевского, 31, г. Ивано-Франковск, 76018, Украина. Тел.: 034253-02-36, +38-050-188-02-61. E-mail: yuriy.shparyk@gmail.com ORCID: https://orcid.org/0000-0001-8047-6356
} 
минируется динамика запасов углерода количеством и интенсивностью санитарных рубок.

Изменения объема продуцирования кислорода ельниками в процессе усыхания в подавляющем большинстве (на 91\% объектов) имеют тенденцию к уменьшению - в среднем на 8,0\%. По группам возраста эти изменения имеют тенденцию к увеличению потерь объемов выработки кислорода от средневозрастных и приспевающих к спелым ельникам. Изменения объема выработки кислорода ельниками по стадиям усыхания также выровненные: на начальной стадии - уменьшение на уроне $10 \%$; на стадии прогрессирующего усыхания - уменьшение на $12 \%$; на стадии стабилизации усыхания потери почти отсутствуют. Объясняется это максимальными потерями органической массы на стадиях начала и прогрессирующего усыхания.

Установлено, что экологические последствия усыхания ельников Украинских Карпат для большинства показателей - положительные (улучшение фиторазнообразия, формирование устойчивых смешанных древостоев, увеличение запасов депонированного углерода в насаждениях без проведения санитарных рубок), но по отдельным показателям отрицательные (уменьшение запасов депонированного углерода при проведении санитарных рубок, ухудшение эффективности выработки кислорода).

Ключевые слова: ель европейская; типы древостоев; возрастные группы; стадии усыхания; фиторазнообразие; депонирование углерода; продуцирование кислорода.

\section{Ecological results of Norway spruce forests' decline in main forest types of the Ukrainian Carpathians}

\author{
Y. Shparyk ${ }^{1}$
}

Stationary studies of the decline dynamics on the 21st Norway spruce forest stands in the Ukrainian Carpathians were conducted in 2010-2014. The analysis of the research results made it possible to assess the environmental impacts of their decline for the following forest types: wet European cedar pine - Norway spruce fairly poor, wet pure Norway spruce fairly fertile, wet Common beech - Silver fir Norway spruce fairly fertile, wet Common beech Norway spruce - Silver fir fairly fertile and wet

Yuriy Shparyk - Corresponding Member of the Forestry Academy of Sciences of Ukraine, Doctor of Agricultural Sciences, Chief Scientist of the Ukrainian Research Institute for Mountain Forestry after P.S. Pasternak, Grushevskogo str., 31, Ivano-Frankivsk, 76018, Ukraine. Tel .: 0342-53-02-36, + 38-050-188-02-61. E-mail: yuriy.shparyk@gmail.com ORCID: https://orcid.org/0000-00018047-6356
Common beech - Norway spruce - Silver fir fertile. The assessment of the ecological effectiveness of the regional Norway spruce forests has been carried out in the context of solving urgent environmental problems: biodiversity conservation, climate change mitigation, and improvement of the conditions for forest recreation.

Dynamics of the plants' diversity in the spruce forests declining were mainly (on the $91 \%$ of the objects) aimed at increasing of the plant species number- in average on $49 \%$. By age groups, the smallest increase was in pole stands $(23 \%)$, the biggest $(86 \%)$ - in premature and $42-46 \%$ - in the mature and over mature spruce stands. By declining stages, it has established a clear tendency to reduce the intensity of the growth of species number from the stage of initial declining to the stage of declining stabilization. The declining intensity was a key for determining of the dynamics of the plants' diversity.

The dynamics of the carbon storage in the declining spruce forests were mainly (on the $55 \%$ of objects) aimed at increasing too, but the average changes is $-2.3 \%$. Maximum changes in carbon stock were set in the following conditions: wet Common beech Norway spruce - Silver fir fairly fertile- increasing on $3 \%$; wet Common beech - Silver fir - Norway spruce fairly fertile- decreasing on $11 \%$. By age groups, the carbon stock increased in the middle-age and premature, but decreased in the mature and over mature spruce stands. By declining stages, the carbon stock changes were characterized by maximum $(+0.2 \%)$ at the initial stage, minimum (-6.2) - at the stage of progressive declining and average values $(-2.5 \%)$ - at the stage of declining stabilization. Holding and the intensity of sanitary felling determine the dynamics of carbon stocks.

Changes in the volume of oxygen production in the declining spruce forests had the trend to decreasing on the $91 \%$ of objects - an average of $8.0 \%$. By age group, these changes were not significant (from -6.2 to $-9.2 \%$ ), had trend to increasing the losses of oxygen production from middle-age, and pre-mature to mature and over mature spruce stands. By declining stages, these changes were not significant too: at the initial stage was decreasing on $10 \%$; within progressive declining - decreasing on $12 \%$; at the declining stabilization stage - there were practically no losses. It was explained by the maximum losses of organic matter on the initial and progressive declining stages.

It is concluded that the ecological results of the Ukrainian Carpathians spruce forests' decline for most of the indicators are positive (increase of phytodiversity, formation of stable mixed forest stands, increase of the carbon storage without sanitary cuttings), but for some indicators are negative (reduction of the carbon storagewith sanitary cuttings, deterioration of oxygen production efficiency).

Key words: Norway Spruce; forest stand types; age groups; decline stages; phytodiversity; carbon stock; oxygen production; trends. 